\title{
БИБЛЕЙСКИЕ ЦИТАТЫ ВО ВТОРОМ СЛАВЯНСКОМ ПЕРЕВОДЕ ИСТОРИЧЕСКОЙ ПАЛЕИ (ПРЕДВАРИТЕЛЬНЫЕ ЗАМЕЧАНИЯ)
}

$\mathrm{T}$

ермин «парабиблейский текст» представляется достаточно объемным. Это дает возможность использовать его при изучении памятников разных эпох, отличающихся с точки зрения генологии и эстетики ${ }^{1}$. Например, «парабиблейскими» считаются «небиблейские Кумранские рукописи»², а также авторские переработки текстов Ветхого Завета, такие как Апокриф Книги Бытия (Genesis Apocryphon), комментарий к Бытию, а также «переработанное» Пятикнижие 3 . Термин «парабиблейская литература» используется и для произведений, которые содержат мотивы, вдохновленные библейскими текстами. Это, в частности, т.н. апокрифы, которые не согласовываются с официальной позицией, но пользуются в определенных кругах не меньшим авторитетом, чем канонические тексты ${ }^{4}$. По моему мнению, это позволяет использовать данный термин в отношении материала, которым является Историческая палея (далее ИП): собрание библейских текстов, эпизодов, сцен, сгруппированных по многочисленным, снабженным заголовками, разделам. В течение примерно семисот лет это произведение функционировало в византийско-славянском мире ${ }^{5}$. Памятник, который появился в IX веке, славяне переводили по крайней мере трижды; он пользовался

\footnotetext{
${ }^{1}$ О парабиблейской литературе культурного пространства, в котором функционировала ИП или близком ему, см. напр.: A. Miltenova, Reception of Parabiblical (Paratextual) Literature in Mediaeval Bulgaria, FE VI-VII, 2007, p. 9-20.

${ }^{2}$ Cм. The Dead Sea Scrolls Reader, vol. 3. Parabiblical Texts, ed. D.W. PArry, E. Tov with the assistance by C. ANDERson, Leiden-Brill 2004.

${ }^{3}$ Cm. D.K. Falk, The Parabiblical Texts. Strategies for Extending the Scriptures among the Dead Sea Scrolls [The Library of Second Temple Studies], Edinburgh 2007.

${ }^{4}$ Cм. напр.: F. Badalanova-Geller, Cosmogonies and mythopoesis in the Balkans and beyond, SMer 14, 2014, p. 87-147; ср. А. Милтенова, А. АнгушевА, Апокрифи, [in:] История на българската средновековна литература, еd. А. МилтеновА, София 2009, р. 217.

${ }^{5}$ См. напр.: Е.Н. ЗАХАРенко, Л.Н. КомАРОвА, И.В. НечАевА, Новый словарь иностранных слов: 25000 слов и словосочетаний, Москва 2003 [http://slovari.ru/search.aspx?s=0\&p=3068\&di=vsis\& wi=11705; http://slovari.ru/search.aspx?s=0\&p=3068\&di=vsis\&wi=13308] [дата обращения: 30.06 . 2016].
} 
особой популярностью на Руси, о чем, однако, можно судить только на основании сохранившихся списков ${ }^{6}$, так как нет информации о рецепции текста или замечаниях, которые были бы сделаны после его прочтения. Размещенные в кодексах, содержащих, в частности, христианские истории и топографию (Георгий Амартол, Козьма Индикоплов), объяснения литургии, жития, проповеди и псевдоканонические тексты, славянские переводы ИП особым образом, вероятно, должны были заменять собой Ветхих Завет в представлении христианина византийско-славянского мира, а точнее, пространства Slavia Orthodoxa ${ }^{7}$.

Уверенно можно сказать, что использование термина «парабиблейский» в этом контексте более адекватно, чем определение «псевдобиблейский». Важнейшими факторами, которые не позволяют утверждать, что ИП относится к имитирующим или наследующим Ветхий Завет произведениям, являются оригинальное (хотя и спорное, а в некоторых вариантах ошибочное) заглавие, а также использование большого количества заимствований ненарративных текстов (поэзии). Нужно подчеркнуть, что литературное содержание ИП (функционирование в традиции, которая была близка официальной; структура и диапазон текста; требования, предъявляемые потенциальному читателю) находится на несравненно более высоком уровне, чем содержание псевдоканонических произведений (или буквально апокрифических $)^{8}$.

Наличие цитат из Писания в литературе византийско-славянского мира осмысливается и анализируется на протяжении нескольких десятилетий - в последних работах обращается внимание на недостаточно полный характер рефлексии. Ситуацию точно характеризует утверждение, что „проблема выявления и атрибуции цитат в средневековой литературе достаточно

\footnotetext{
${ }^{6}$ Сохранилось ок. 30 списков I-го перевода XV-XVII вв., все восточнославянские, кроме того, несколько списков II-го перевода, сербских и среднеболгарских XIV-XVI вв.

${ }^{7}$ О Палее см.: Chr. Вӧттвісн, Palaea/Palaja. Ein byzantinisch-slavischer Beitrag zu den europaicheschen Historienbibeln, [in:] Fragmentarisches Wörterbuch. Beiträge zur biblischen Exegese und christlichen Theologie. Horst Balz zum 70 Geburtstag, ed. K. Schiffner, K. Wengt, W. Zager, Stuttgart 2007, p. 304-313; А. МилтеновА, Палея, [in:] Старобългарска литература. Енииклопедичен речник, еd. Д. ПетКАнова, ${ }^{2}$ Велико Търново 2003, p. 345-346; Р. СТАнков, Историческая Палея - памятник древней болгарской культуры, Pbg 10.4, 1986, p. 55-63, О.В. Творогов, Палея историческая, [in:] Словарь книжников и книжности Древней Руси (вторая половина $X I V-X V I$ в.), pars 1 et 2, еd. Д.С. ЛихАчев, Ленинград 1988-1989, 2, p. 160-161.

${ }^{8}$ В то же время нужно обратить внимание на функционирование термина 'парабиблейский текст,' 'парабиблейская традиция' в контексте устной народной традиции. Понимаемая таким образом 'парабиблейская традиция', хотя и без связи с обстоятельствами функционирования ИП, должна была бы развиваться «среди европейских крестьян параллельно с элитарной культурой в связи с глубокой адаптацией церковного катехизиса, приспособленного к миру деревни», цит. по: М. ZowCZaк, Przedmowa do wydania drugiego, [in:] M. ZowCZaк, Biblia ludowa. Interpretacje wątków biblijnych w kulturze ludowej, Torun 2013, p. 12.
} 
трудоемка, она осложняется еще и тем, что цитаты достаточно подвижны, зачастую мы сталкиваемся просто с аллюзиями и реминисценциями"9. Особой проблемой является вопрос библейских цитат в парабиблейском произведении - в ИП. Это произведение - кроме фрагментов, явно заимствованных из небиблейских источников - само по себе является парафразом первых книг Ветхого Завета, то есть цитатой из гипертекста ${ }^{10}$ с включением прямых цитат и отсылок. Конечно, по этой причине легко поддаться искушению и рассматривать нарратив и сюжет ИП в качестве библейских, впрочем, нужно помнить о различиях библейского текста и собственного текста автора ИП. Возможно, что именно в ИП библейские нарратив и сюжет - или, скорее, созданные по модели библейских - не представляются нам «пустой и закостенелой формулой, но полным жизни и динамики «приключением», у которого всегда есть своя, заданная автором, структура и логика» ${ }^{11}$. Посмотрим на пример специфического использования текста Писания в ИП (на материале второго славянского перевода, в котором - в отличие от т.н. первого перевода - больше библейских цитат ${ }^{12}$ ). Рассмотрение этого примера позволит охарактеризовать цитаты (прямые) и подчеркнуть их отличие от переработок, заимствований и аллюзий, основываясь на новейших

\footnotetext{
9 А.В. Сизиков, Новозаветные ицитаты в древнерусском переводе Жития Андрея Юродивого, [in:] Священное Писание как фактор языкового и литературного развития. Материаль международной конференции „Священное Писание как фактор языкового и титературного развития (в ареале авраамических религий)", Санкт-Петербург, 30 июня 2009 г., еd. Е.Н. МЕщЕРСКАЯ, Санкт-Петербург 2011, р. 159.

${ }^{10}$ Zob. М. ГАрдзАнити, Библейские цитаты в иерковнославянской книжности, Москва 2014, p. 13-14.

${ }^{11}$ Цит. по: D. DzIadosz, Teologiczne przestanie teofanii Boga pod dębami Mamre (Rdz 18,1-16), [in:] Język Biblii. Od słuchania do rozumienia. XXXII Tydzień Biblijny, Lublin (KUL), 29.-30.11.2003, ed. W. PIкоR, Kielce 2005, p. 24.

${ }^{12}$ Т.н. II перевод ИП (далее: ИП ІІ) в списке рукописи Николяц 83 (1425-1435), л. 1216-229a; о рукописи см.: Д. БогдАновић, Инвентар ћирилских рукописа у Југославији (XI-XVII века), Београд 1982, р. 38; Д. МедАКовић, Манастир Савина, Београд 1978, p. 89-96. Представленные здесь фрагменты ИП II в основном соответствуют греческому тексту единственного на сегодняшний день издания Византийской палеи: Палея историческая, [in:] A. VAssILIEv, Anecdota graeco-byzantina [СПВЛ, t. 11], Москва 1893, p. 188-292. Текст Ветхого Завета в староболгарском переводе по спискам: Загребская Библия - опись кодекса в: V. Mošın, Ćirilski rukopisi Jugoslavenske Akademije, I. dio. Opis rukopisa, Zagreb 1955, № 61, p. 117-118; и: Г. Минчев, Пшинская Библия первой четверти XVI века - малоизвестная южнославянская рукопись, содержащая перевод Восьмикнижия, [in:] Священное Писание как фактор языкового и титературного развития. Материаль международной конференции „Священное Писание как фактор языкового и титературного развития (в ареале авраамических религий)", Санкт-Петербург, 30 июня 2009 г., отв. ред. Е.Н. МЕщЕРСКАЯ, Санкт-Петербург 2011, р. 223-240; Пшинская Библия - оПись кодекса в: Б. ХрИСтова, Е. МусаковА, Е. УзУновА, Опис на ставянските рбкописи в Цбрковно-историческия и архивен институт - София, t. 1. Библейски книги, еd. Кл. Иванова, София 2009, p. 26-27 (№ 1, иллюстрации I-V, p. 149-150), и: Г. Минчев, op. cit.
} 
подходах к подобным заимствованиям в текстах ареала Slavia Orthodoxa13, а также оценить творческие способности автора ИП в использовании первоисточника для создания оригинального литературного произведения ${ }^{14}$.

Марчелло Гардзанити в своей классификации выделяет следующие типы заимствований из гипертекста:

I. Ссылка на понятия и реалии (события или лица):

1. Упоминание без какого-либо комментария. 2. Толкование понятий или описание реалий (изложение событий, перечень их участников и пр.).

II. Цитата:

[1.] Аллюзия. [2.] Парафраз или пересказ. [3.] Прямая цитата.

III. Инсценировка (пересказ события или понятия в диалоге):

[1.] Парафраз. [2.] Цитата. [3.] Композиционное объединение цитат ${ }^{15}$.

Итак, первый специфический тип, толкования и упоминания, можно обнаружить в ИП в одной из глав о делах Израиля под водительством Иисуса Навина. Это не чистый тип, предложенный М. Гардзанити, а лишенная комментария «отсылка к реальности», она вводится через конкретизацию: мысли придается персональный и событийный характер. Глава Об Аендоре (ИП II) была названа издателем английского перевода Греческой палеи «удачной обработкой» Пс 82(83),10-11 ${ }^{16}$. Топоним 'Аендор' („Сделай им то же, что Мадиаму, что Сисаре, что Иавину у потока Киссона, которые истреблены в Аендоре, сделались навозом для земли"17) превратился в имя героя

\footnotetext{
${ }^{13}$ Проблема классификации и типологии библейских цитат в текстах православных славян уже поднималась в следующих работах: Р. Пикио, Функцията на библейските тематични ключове в титературния код на православното, [in:] Р. Пикио, Православното славянство и старобългарската културна традиция, София 1993, p. 385-435; A.E. NAUмоw, O kartotece cerkiewnosłowiańskich użyć biblijnych, RSl 44, 1983, № 1, p. 21-29; Кр. СТАнчев, За художествена специфика на старобългарската литература, [in:] Кр. СтАнчев, Стилистика и жанрове на старобългарската литература, София 1985, р. 5-21.

${ }^{14}$ Необходимо, кроме того, обратить внимание на двойственную - историкоформирующую и нехудожественную - природу (а скорее функцию) библейских цитат в ИП.

${ }^{15}$ По: М. ГАРдЗАНИТИ, op. cit., p. 13-14.

${ }^{16} \mathrm{C}$ коммент.: The Palaea, as it does elsewhere, understood 'en' to mean 'by' and imagined that a fictional character named 'Endor' was responsible for their destruction [...]. The author may have placed this episode after the death of Joshua, because the preceding verse of the Psalm describes events occurring at the time of the judges. The details of the story bear some similarities to the account of Ehud's killing of Eglon king of Moab in Judg 3:16-26 [...], цит. по: W. Adler, Palaea Historica („The Old Testament Story"). A new translation and introduction, [in:] Old Testament Pseudepigrapha. More noncanonical scriptures, vol. 1, ed. R. Bauckham, J.R. Davila, A. Panayotov, Michigan 2013, p. 650, прим. b (полностью на р. 585-672).

${ }^{17}$ Библейские цитаты по изданию: Библия. Книги Священного писания Ветхого и Нового Завета. Синодальный текст [http://www.biblioteka3.ru/biblioteka/biblija/] (дата обращения: 1.07.2016).
} 
- освободителя из-под ига халдеев. В целях повествования был создан герой

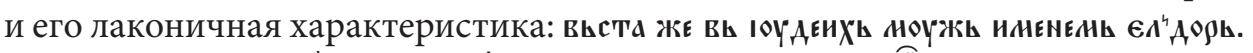

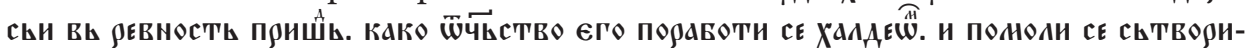

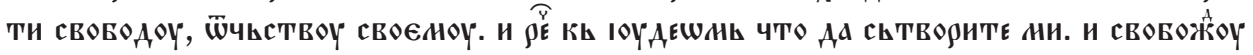
ш̈чьство ваше $\ddot{\boldsymbol{w}}$ роүкоү ХаА

В ИП есть еще один герой, прообраз которого напрасно искать в Писании - в главе O переписи народа (ИП ІІ). Царь Давид планирует переписать народ Израиля; когда он поручает сделать это Иоаву, последний отказывается, дабы не преступить закон (ср. 2 Цар 24,1-3), однако, позднее „слово царя Иоаву и военачальникам превозмогло; и пошел Иоав с военачальниками от царя считать народ Израильский” (2 Цар 24,4). Тем временем автор ИП в это место повествования вводит образ другого поверенного, который исполня-

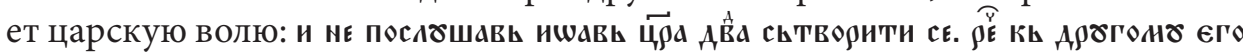

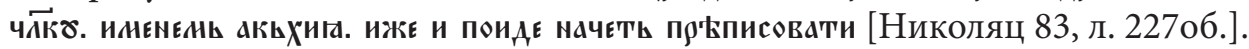
Особенности этого персонажа ${ }^{18}$ помогают Иоаву остаться праведником, он преображается - по контрасту - в антагониста царя, который свою волю поставил выше воли Господа.

Практически в стороне от упомянутой классификации остается еще одно (хотя и похожее) вмешательство автора ИП в текст Восьмикнижия - оно касается конструкции образа: в главе Слово о Деворе (ИП ІІ). Из истории смелой девы, принадлежащей в Израиле к судейскому кругу, которая появляется в Суд 4 и 5, заимствовано только имя. Это сделано для того, чтобы сформировать образ, связанный с повествованием о Юдифи (Июдифь 8-16). Начало главы не оставляет никаких сомнений:

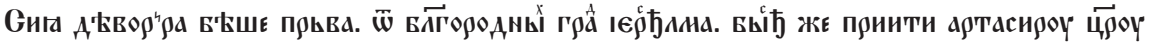

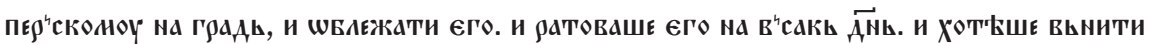
вь нюего. сьпротивгахоү же се Граӝане. Аон

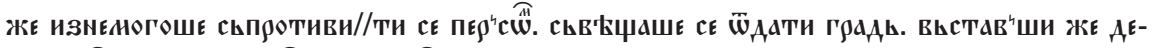

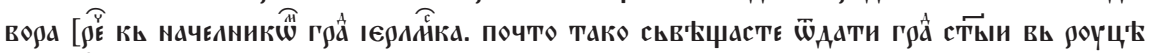

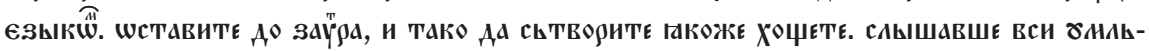

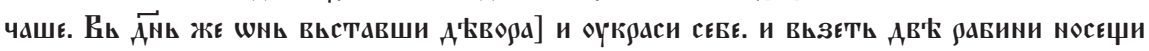

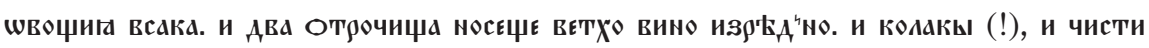

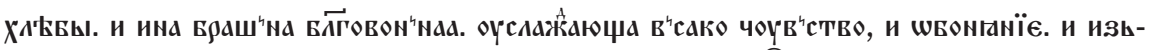

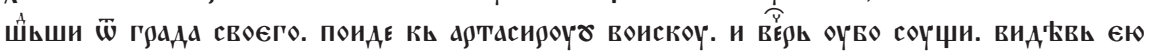

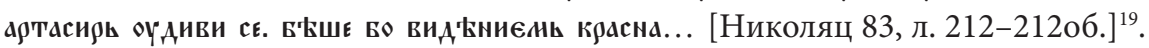

\footnotetext{
${ }^{18}$ У. Адлер подчеркивает, что [t] his name is unknown in the account told in 2 Samuel. The name is possibly related to the Greek word 'achreia' ('useless'), цит. по: W. AdLER, op. cit., p. 668, прим. b. Если принять эту этимологию имени, оно приобретает иронические черты - Ахия оказывается, с точки зрения царя, исключительно полезным.

${ }^{19}$ Дополнение в квадратных скобках по списку ИП из собрания Музея Сербской православной церкви в Белграде, сигн. 42 (далее: МСПЦ 42), л. 104об. 25-30.
} 
Этот пример подтверждает правильность мнения, согласно которому для автора ИП важнее было описать ход разворачивающихся событий, заострить стремительную сюжетную линию, усилить яркость героев, нежели передать скрупулезность размышлений об истории избранного народа, теологические проблемы или мораль - содержание нравственного характера дается почти мимоходом.

Среди способов цитирования содержания Библии в ИП особого внимания заслуживает инсценировка (третий тип по классификации М. Гардзанити). В сущности, это определенная стилистическая обработка, например, изменение порядка слов в предложении или изменение подлежащего и дополнения, а прежде всего изменение формы словесного выражения (т.е. превращение нарратива в третьем лице в монолог или диалог, а значит, использование прямой речи). Можно предположить, что инсценировка требует значительных композиционных и стилистических способностей, обладание которыми уменьшает риск появления ошибок при трансляции исходного текста.

С этой техникой в ИП мы встречаемся, в частности, в главе О жене Урии, в которой описывается драматическая судьба Вирсавии (ИП II): если в Писании „Урия спал у ворот царского дома со всеми слугами своего господина, и не пошел в свой дом" (2 Цар 11,9), то в ИП мы знакомимся с этой

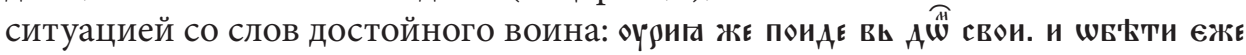

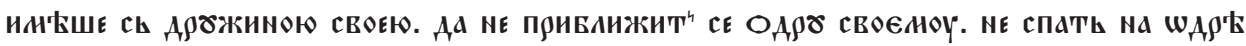

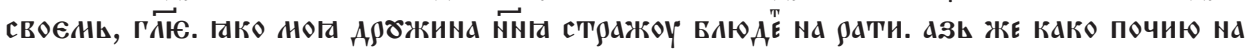

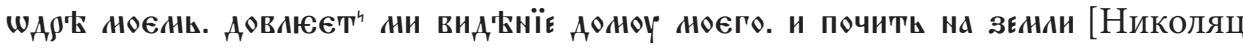
83, л. 221об.].

Подобным образом прямая речь включена в библейский нарратив в главе О ияаре иудейском Озии (ИП II). Во второй книге Паралипоменон мы читаем о царе: „возгордилось сердце его на погибель его, и он сделался преступником пред Господом Богом своим, ибо вошел в храм Господень, чтобы воскурить фимиам на алтаре кадильном" (2 Пар 26,16) - в свою очередь, в ИП его слова звучат так: „сказал царь Озия [священнику]: «позволь

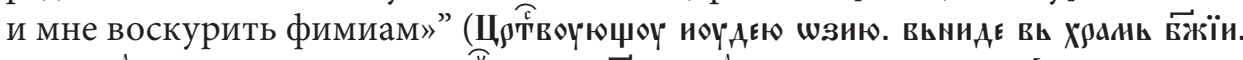

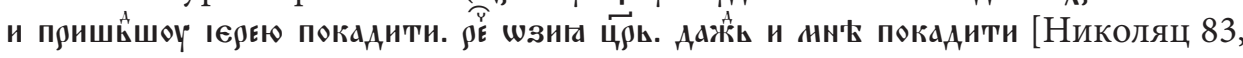
л. 228об.]).

Еще один вариант упомянутой выше инсценировки - фокусирование действия (нарратива) не на ветхозаветном герое. Это приводит к изменению композиции персонажей. Обратимся к истории Иеффая - когда оказывается, что в качестве благодарения за победоносное возвращение из похода против аммонитян он поклялся принести в жертву собственную дочь, библейский Иеффай вступает с дочерью в разговор, объясняя причины своих действий: 


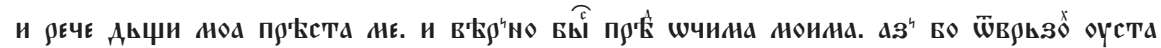

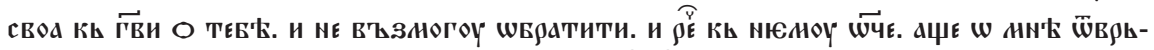

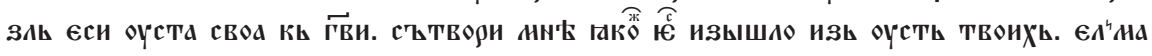

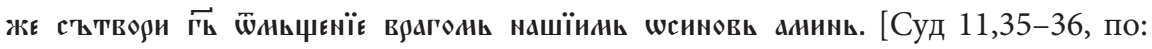
Загребская Библия, л. 311об.-312].

Тем временем в ИП именно девушка инициирует разговор; таким образом, она приобретает более активную позицию героя, наделенного речью:

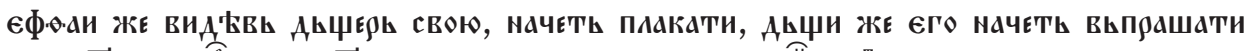

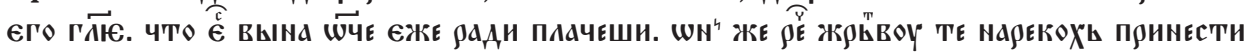
гоу Б्ү [Николяц 83, л. 198об.].

История обета и утраты Иеффая принадлежит, впрочем, к тем повествованиям, в которых автор ИП отчетливо воздействует на читателя посредством эмоций, вызванных специфической переработкой библейского мотива. В книге Судей последние месяцы жизни девушки представлены коротко, без драматизма констатируется ее прощание с миром: идє сана и Ароүгиню.

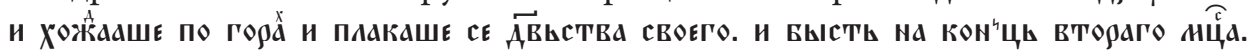

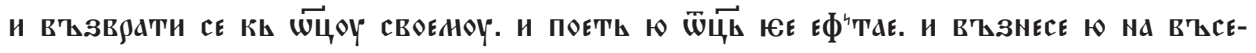

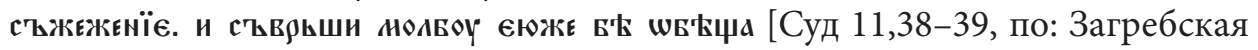
Библия, л. 312], в то же время в ИП мы находим опИсание: и втшє Х゚Аєчии $\mathbf{3 d}$

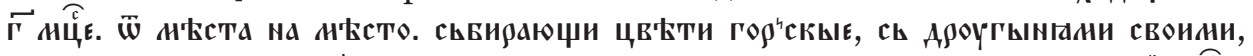

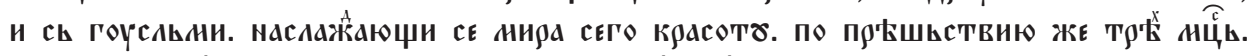

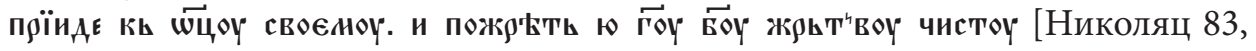
л. 198об.-199]. Демонстрация радости последних дней (с цветами, музыкой) создает явный контраст между невинностью принесенного в жертву ребенка и его страшной судьбой, уготованной ему несчастным отцом. Может быть, именно своеобразная суровость описания, связанная с отсутствием комментария, действует так проникновенно. Начало разговора с дочерью Иеффая ввводит в повествование дополнительный драматизм: предпринятая ею попытка прояснить причины грусти Иеффая неизбежно приводит к трагедии.

Стоит отметить, что в ИП используются приемы противоположные инсценировке (в которой можно увидеть особую драматизацию библейского нарратива), а именно изъятие фигурирующих в Писании высказываний в форме прямой речи (монологи, диалоги), а также многочисленных деталей, таких как различные обстоятельства, сопутствующие событиям. Это делается ради сокращения содержания и обобщения - краткого пересказа того, чему посвящено повествование. Например, в главе О моавском иаре Балаке (ИП II) автор ИП явно избегает повторения пространных увещеваний и пророчеств прорицателя Валаама, записанных последовательно в четырех фрагментах Книги Чисел (Чис 23,7-10, Чис 23,18-24, Чис 24,3-9 


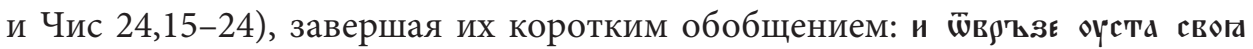

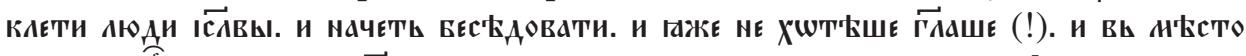

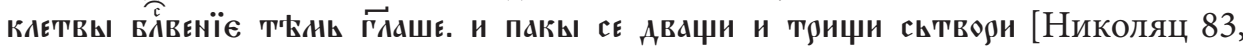
л. 184 об. $]^{20}$.

Категорию «композиционного объединения цитат» в ИП представляют случаи пересказа и сокращения - как в высказываниях в форме прямой речи (репликах), так и в сюжетной линии, а также в описании деталей художественного мира. Сокращения (или скорее подборки из) прямой речи можно найти в следующих главах $О$ скинии откровения и О святых священнических ризах (ИП ІІ). В этих двух самых коротких главах ИП используется главным образом нефабулярный материал: они состоят почти полностью из напоминания слов Бога, призывающего Моисея подготовить надлежащие объекты культа и утварь. Эти главы представляют из себя пересказ ряда фрагментов Книги Исход (очередно: Исх 25,40, Исх 26, Исх 28,1-14, Исх 30,10, Исх 27,1 и Исх 30,1-10):

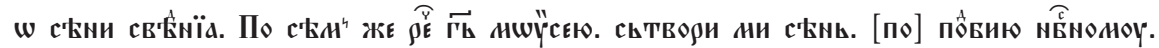

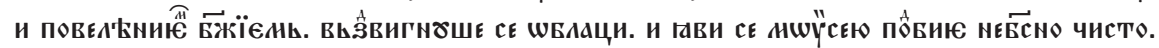

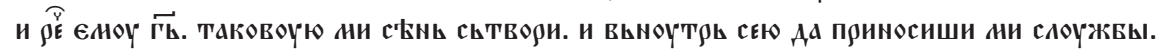

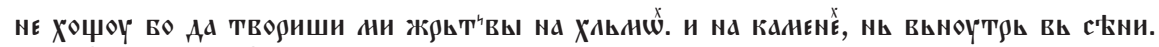

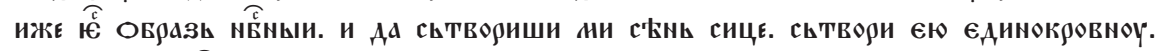

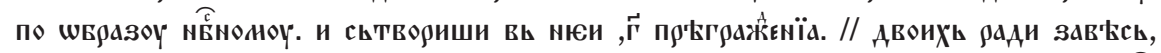

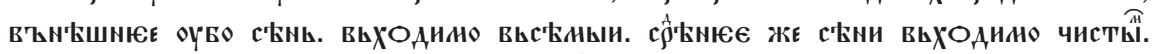

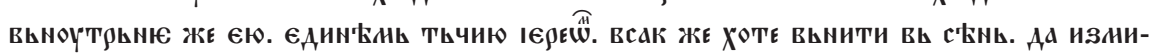

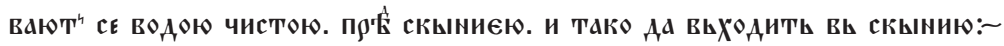

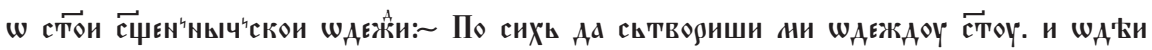

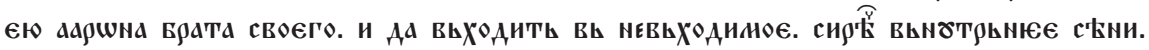

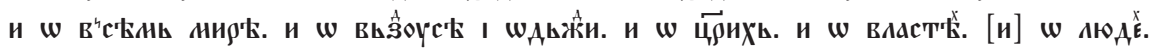

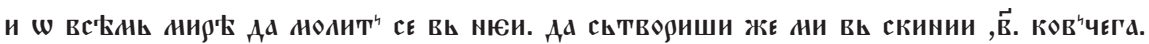

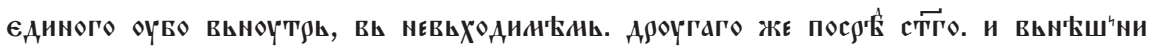

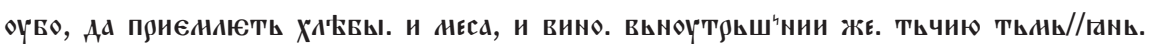

\footnotetext{
20 Другой пример мы находим в главе О восстании на Моисея (ИП ІІ), которая начинается с констатации недовольства евреев из рода Рувена и Дафана, связанного с запретом им при-

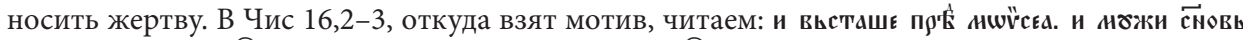
Іер

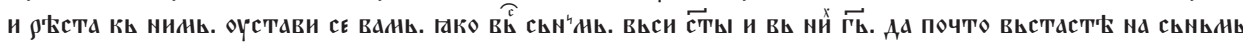
Гнь [Пшинская Библия, л. 119об.]. В ИП тем временем нарекания звучат более весомо, они

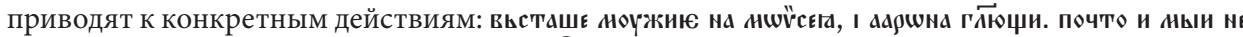

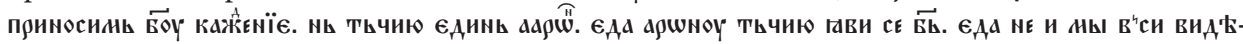

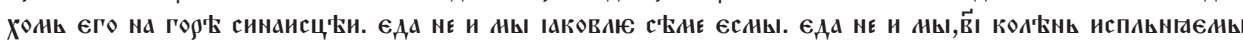
[Николяц 83, л. 175]. Речь восставших евреев в ИП является парафразом Писания, изложением, которое позволяет читателю получить четкую информацию, касающуюся сути дела.
} 


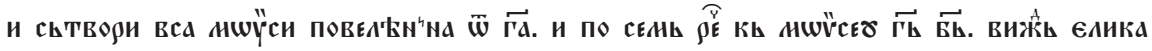

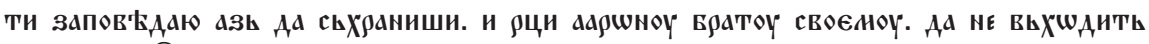

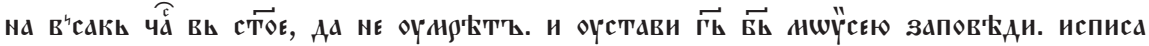

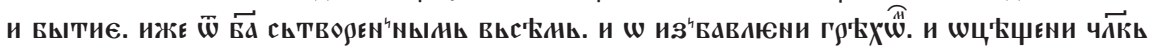
сьгећшаючїй [Николяц 83, л. 172об.-173об.] ${ }^{21}$

Несколько раз в классификации М. Гардзанити появляется тип цитаты, понимаемой не только как вариант инсценировки (в рамках третьего типа), но и как прямой перенос фрагмента библейского текста в другое произведение (прямая цитата в рамках второго типа), и как парафраз.

Категория парафраза дает возможность включить в нее различные приемы работы с исходным текстом. Один из примеров парафраза в ИП можно найти в главе О Амалике (ИП II). Она повествует о противостоянии израильтян с амаликитянами в Рефидиме (Исх 17,8-16) 22 :

\begin{tabular}{|c|c|}
\hline ИП II [Николяц 83, л. 165-165об.] & Загребская Библия, л. 86об.-87 \\
\hline 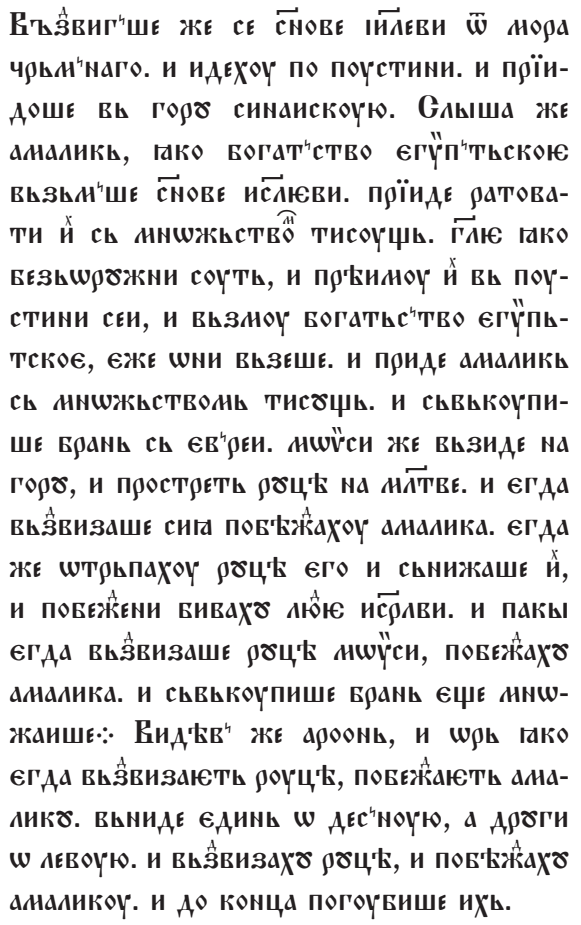 & 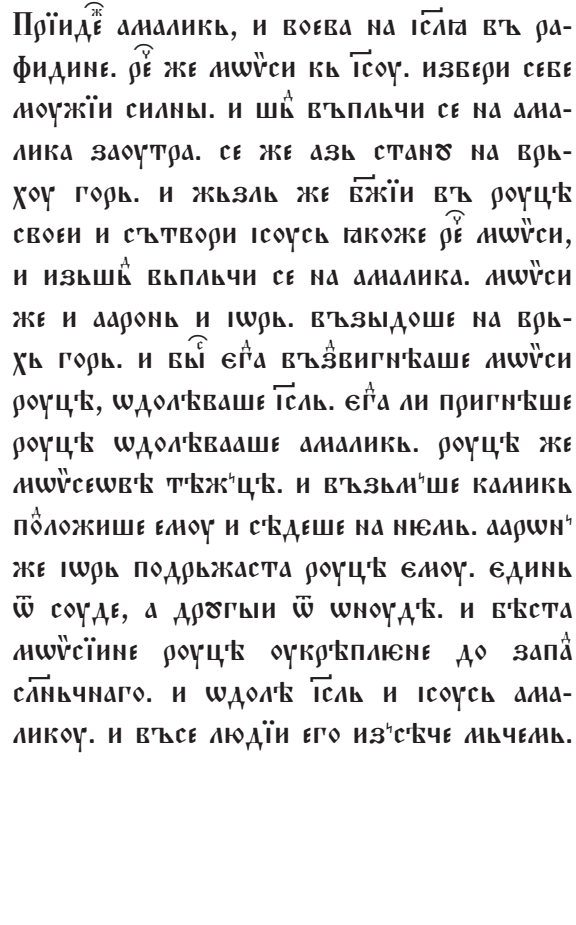 \\
\hline
\end{tabular}

\footnotetext{
${ }^{21}$ Дополнение в квадратных скобках по списку МСПЦ 42.

${ }^{22}$ В таблице сравнивается фабулярная часть главы ИП ІІ без поэтических комментариев и начало библейской главы Исх 17,8-13.
} 
Оба фрагмента равны по объему, но значительно отличаются друг от друга деталями. ИП подробно описывает мотивы нападения амаликитян на избранный народ, но игнорирует образ Иисуса Навина, первого предводителя и архитектора победы израильтян - может быть потому, что в центральной части повествования именно Патриарх занимает главное место. Это лишает Моисея возможности предсказать ход событий - иначе трудно было бы не вспомнить об Иисусе Навине. В то же время образ простирающего руки и взывающего Моисея прямо интерпретируется как «молитва».

Конечно, в ИП можно выявить значительно больше примеров категорий, предложенных М. Гардзанити - типов связи с библейским гипертекстом. Можно добавить и другие виды вмешательства в первоисточник, которые трудно напрямую связать с предложенной схемой. Таким образом, к жанровым можно добавить художественные приемы, показывающие специфическую чувствительность автора ИП относительно конструирования сюжетной линии, нарратива и элементов литературного мира.

В тексте ИП заметен эффект авторских усилий, которые можно назвать попыткой углубления изобразительного, визуального слоя отдельных сцен. Они заключаются в обогащении библейского содержания элементами, принципиально с ним созвучными, но более зрелищными с точки зрения фабулы. Например, введение ангелофании и реплики нового, с точки зрения Писания, героя - ангела - вместо трансляции реплик аутентичных ветхозаветных героев. Таким образом текст Писания обогащается в главе $O$ жене Урии: в эпизод обращения пророка Нафана к царю Давиду (2 Цар 12,1) введен персонаж ангела. Он говорит с пророком, а затем участвует в разговоре Нафана с царем:

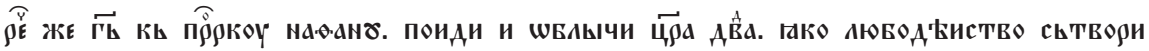

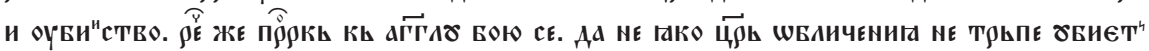

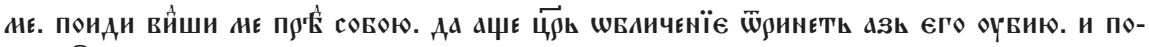

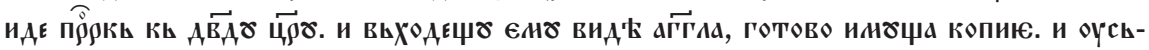

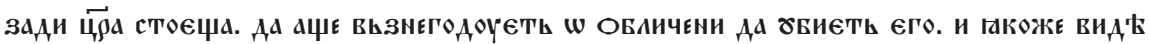

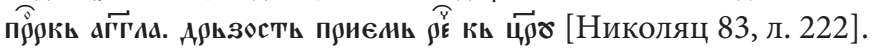

Явление ангела Господня вводится в фабулу главы $O$ переписи народа (ИП II) ранее, чем это делается в фабуле Писания - непосредственно после того, как царский чиновник начинает перепись:

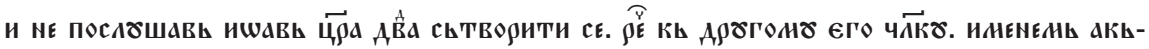

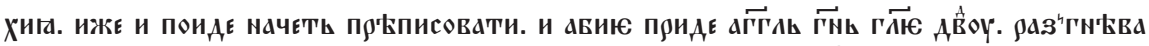

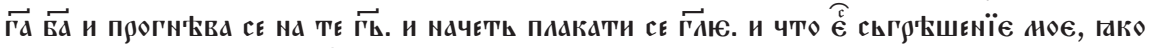

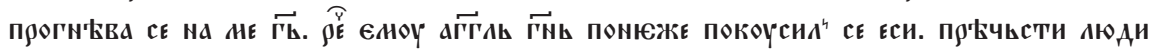

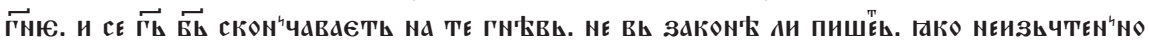




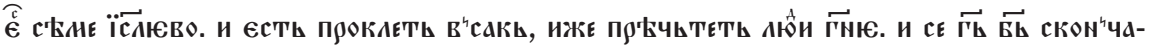

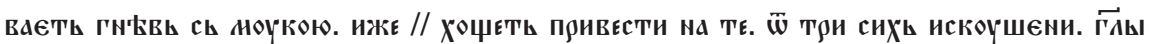

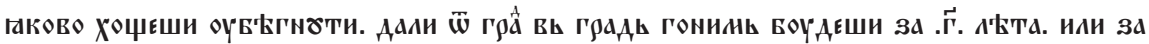

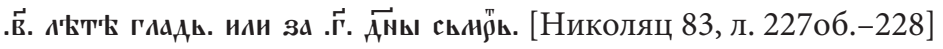

В Писании пророк Гад передает царю предначертание наказания вместе с возможностью его выбора (2 Цар 24,16), ангел же Господень появляется в этом эпизоде только после уничтожения семидесяти тысяч человек, когда „простер [...] руку свою на Иерусалим, чтобы опустошить его” (2 Цар 24,16). Уверенно можно сказать, что ангелофания представляется более ярким и проникновенным для воображения читателя явлением, чем образ достойного, поучающего царя, пророка. Оба упомянутых примера представляют собой одновременно реализацию описанной выше идеи; произошло не только изменение авторства избранных произведений, но были созданы новые персонажи, был введен новый элемент воображаемого мира библейской фабулы. Для сохранения ветхозаветного содержания была использована новая форма.

Благодаря внимательному чтению ИП можно сделать еще одно наблюдение. Оно касается хронологического порядка историй - на микроуровне, то есть в рамках конкретных глав. Как правило, структура содержания соответствует библейскому образцу ${ }^{23}$, но четко прослеживается тенденция изменения последовательности библейских эпизодов в богатых, с точки зрения материала, главах, посвященных одному основному герою (Самсону, Саулу и Давиду). Прослеживается тенденция изменения логики и последовательности событий внутри эпизодов. Например, в истории Давида ИП переносит эпизод его свадьбы с Мелхолой (1 Цар 18) в отрывок, предшествующий походу против амаликитян (1 Цар 15) и противоборству с Голиафом (1 Цар 18); «злой дух» возмущает Саула в момент между помазанием Давида на царство (1 Цар 16,1-13) и попыткой лишения его жизни (1 Цар 18,1-3,10); впечатление, произведенное видением Самуила во время встречи с волшебницей из Аендора (1 Цар 28) становится в ИП причиной смерти Саула, хотя согласно Писанию, царь уже после этой встречи отправляется в поход

\footnotetext{
${ }^{23}$ Исключения для произведения такого объема немногочисленны: глава О горькой воде Мер$p ы$ (основанная на Исх 15,22-17) размещена после главы О Амалике (Исх 18,8-16); глава О законе, данном Богом Моисею (Исх 20) размещена после О восхождении Моисея на гору Синай (Исх 24, Исх 32); глава О Ковчеге Завета (Исх 25) размещена после О втором восстании на Моисея (Чис 16, Чис 15); глава Об укусах змей (Чис 21) размещена после О земле обетованной (Чис 13 и Чис 14); глава Об искушении Озы (2 Цар 6,3-7) размещена после О земле обетованной (Чис 13 и Чис 14), но перед О манне небесной (Исх 16, Чис 11); глава История Иаили (Суд 4) размещена после истории Самуила (1 Цар) и после Истории священника Илия (1 Цар); главы: История Самуила (1 Цар) и История священника Илия (1 Цар) размещена после главы О судьях из колена Левия (Суд 19).
} 
против амаликитян (1 Цар 15) и оказывается свидетелем смерти своих сыновей (1 Цар 31) в день своей собственной смерти (1 Цар 31,6). Это не должно свидетельствовать о недостаточном знании первоисточника; скорее, это довод в пользу субъективного выбора ветхозаветных эпизодов, творческого подхода к гипертексту и естественной заботы о яркости повествования. Нужно подчеркнуть, что ни одно из этих изменений не приводит к искажению смысла Писания.

Рассмотрим теперь другой конструктивный элемент ИП - прямую цитату (второй тип классификации). Обращает на себя внимание факт, что прямые цитаты выполняют в ИП две функции: историообразующую (как часть нарратива, повествования) и нехудожественную - как обобщение, доминанты сцен и эпизодов (или скорее глав). В ИП есть множество небольших - размером с половины предложения или библейской фразы до двух-трех предложений - цитат, вплетенных в структуру глав. Можно предположить, что во многих случаях автору ИП было трудно найти фрагменты, которые были бы параллельны библейским, но в то же время обладали бы такой же повествовательной силой - фрагменты высказываний конкретных персонажей или включенные в пересказ «предвидения» библейской истории. Автор и комментатор английского перевода Палеи указывает примерно на шестьдесят таких мест $^{24}$. Здесь я представлю наиболее характерное из них. Прежде всего, по причине большого объема оно функционирует практически без изменения исходного текста - как по отношению к репликам героев, так и по отношению к нарративу. То есть мы имеем дело с прямой цитатой. Это глава $O$ горькой воде Мeppbl, полностью состоящая из библейской перикопы (Исх 15,22-27) 25 :

\begin{tabular}{|c|c|}
\hline ИП II [Николяц 83, л. 166об.-167] & Загребская Библия, л. 84-84об. \\
\hline 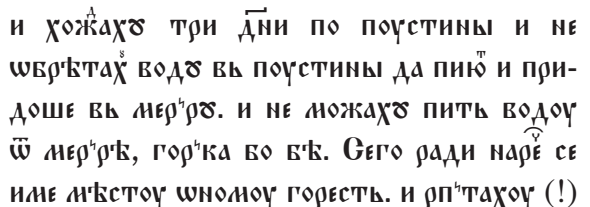 & 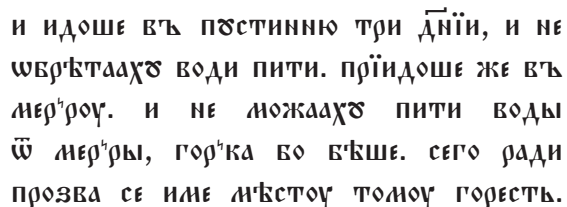 \\
\hline
\end{tabular}

\footnotetext{
${ }^{24}$ CM. W. Adler, op. cit., p. 585-672.

${ }^{25}$ Фрагмент Исх 15,22-27.16,1 - а значит, почти вся глава О горькой воде Мерры - представляет из себя перикопу, как третье чтение на Богоявление Господне (ср. 3. РиБАрова, 3. ХАуптовА, Григоровичев паримејник. Текст со критички апарат, Скопје 1998, р. 27). Возможно, хорошее знание текста и осведомленность о его использовании во время литургии привели к выделению этого фрагмента в самостоятельную главу ИП (II). Это единственный фрагмент ИП, который - как цитату из Ветхого Завета - можно связать с сегментацией библейского текста для лекционария.
} 


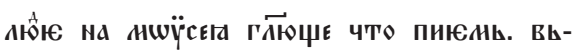

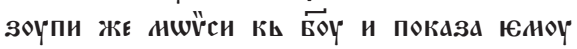

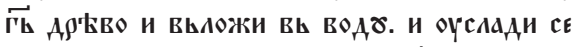

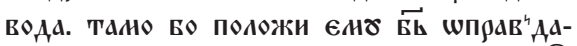
нита и соүА АџЕ слоүХ Го. и оүГОА

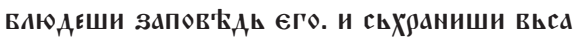

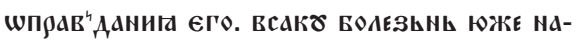

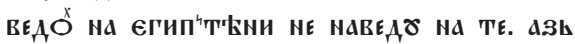
БО ЄСЬАЬ ГЬ ИСЦЕАТЕвИ ТЕ. и ПЮЙАОШЕ ВЬ

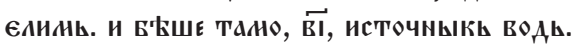

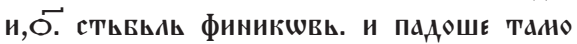

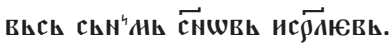

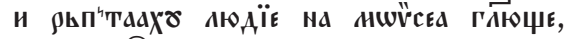

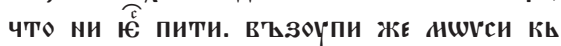

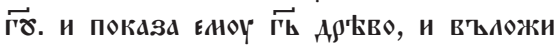

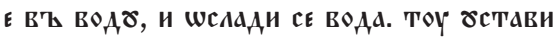

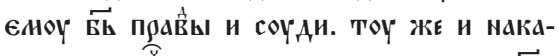

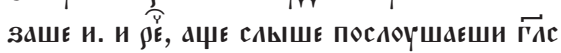

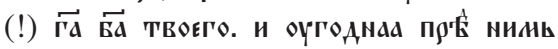
с'ътвориши. и в'ъноүшиши заПов'Ади

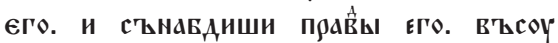

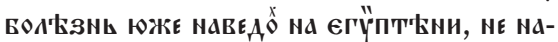

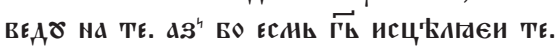

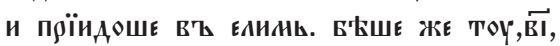
источникь водЬ. И,О. стТБАЬ финиковь. И сташе тоү в'Ъ Краи воды.

Как уже говорилось выше, второй тип заимствований/упоминаний в виде прямых цитат выполняет в ИП нефабулярную функцию 26. Библейских цитат, выполняющих функцию обобщения, в ИП около двадцати, большинство из них - поэтические фрагменты Псалтири ${ }^{27}$. Они предваряются формулировками: «говорит псалом», «свидетельствует Псалтирь», «упоминает Давид», «так, как упоминает Писание», «упоминает Псалмопевец» (то есть «Гимнопевец»):

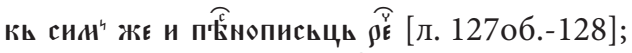

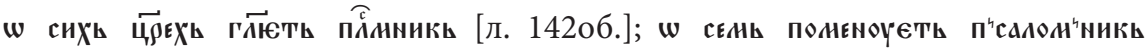

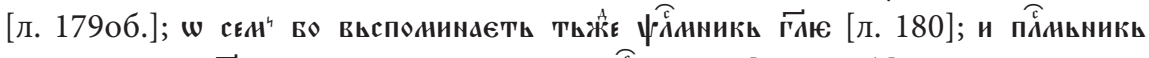

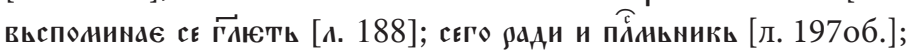

\footnotetext{
${ }^{26}$ В нарративе автор ИП трижды обращается к авторитету Писания, он ссылается на определенные библейские книги, но не приводит их содержания. Во втором славянском переводе ИП (иначе, чем в доступном греческом тексте по изданию Васильева и первом переводе, где первая из указанных ниже цитат не появляется) ссылки выглядят так: 1. акожє повъдоүють

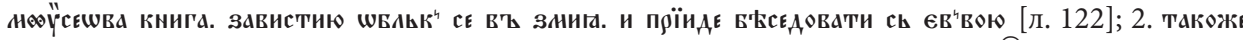

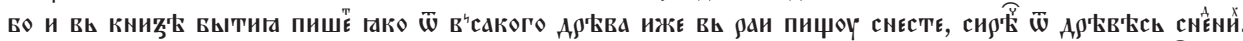

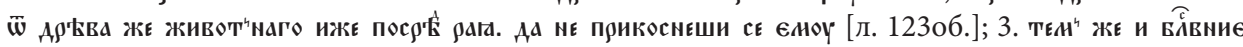

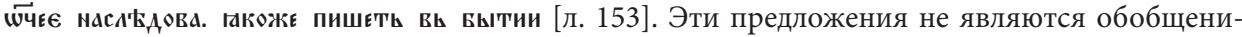
ем отдельных эпизодов, так как появляются в середине истории, в продолжении нарратива (как ассоциация или указание), а не в начале или в конце глав, как большинство цитат из Псалтири (или литургической поэзии).

${ }^{27}$ Пс 9,17; Пс 29(28),8; Пс 78(77),35; Пс 78(77),55; Пс 81(80):17; Пс 83(82),11; Пс 83(82),12; Пс 87(86),4; Пс 88(87),6-7; Пс 95(94),7-11; Пс 95(94),10-11; Пс 105(104),11; Пс 106(105),17-18; Пс 106(105),28; Пс 106(105),30-31; Пс 107(106),40; Пc 110(109),2; Пс 110(109),4.
} 


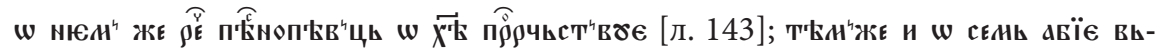

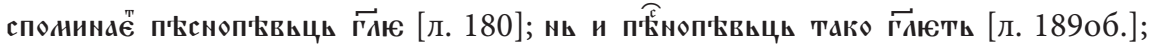

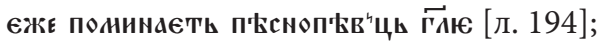

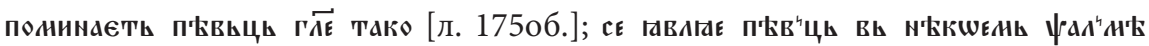

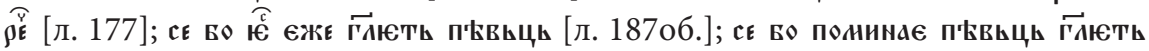
[л. 209об.].

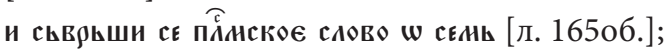

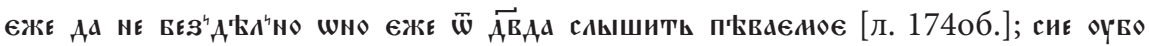

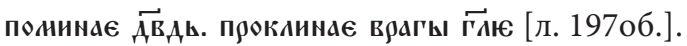

Они распределены в тексте неравномерно, например, в главах, посвященных Аврааму нет ни одной подобной цитаты, но их относительно много в третьей тематической части ИП, то есть в описании судьбы Израиля после смерти Моисея. В нефабулярной функции обобщения в ИП выступают и четыре фрагмента, связанные с Новым Заветом (слова Иисуса из Евангелия и фрагменты апостольских Посланий $)^{28}$. Это новозаветные цитаты:

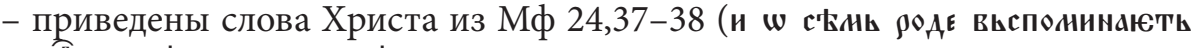

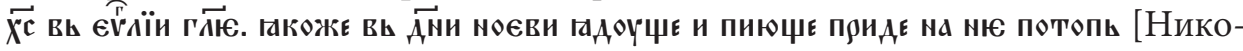
ляц 83, л. 127об., глава Об Авеле]);

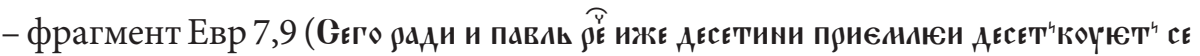
[Николяц 83, л. 140], глава О Лоте);

- стих, заканчивающий размышления о символике креста - нефабуляр-

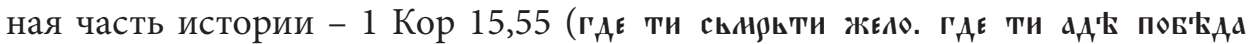
[Николяц 83, л. 177об.], глава Об укусах змей);

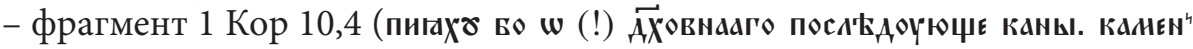

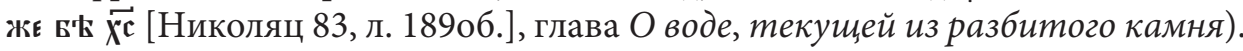

Это своеобразный выбор. Несомненно, можно было бы найти выдержки из Ветхого Завета, которые тематически отвечали бы этим цитатам, впрочем, их так немного, что встает вопрос: почему выбраны именно эти цитаты? Сделано это было точно неслучайно. Представляется правильным рассматривать их в качестве подсказок для интерпретации Ветхого Завета в свете Нового.

В общей сложности, ветхо- и новозаветных прямых цитат и отсылок (но не парафразов) различного объема, выполняющих различные функции, а именно коррелирующих нарратив и высказывания героев, обобщающих отдельные

\footnotetext{
${ }^{28}$ Пятая новозаветная цитата ИП - это фрагмент Евр 7,3, относящийся к Мелхиседеку (вєз

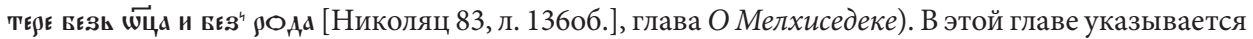
на сходство Мелхиседека и Христа. Она связана с оригинальным небиблейским произведением, которое является основой этой части ИП. То есть речь идет о копировании источника, а не об оригинальном решении автора ИП разместить очередную цитату именно в данном месте.
} 
главы и комментарии описываемых событий, можно насчитать в ИП ІІ более ста двадцати. Это цитаты из следующих книг: Бытия (48), Исхода (26), Псалтири (19), Левита (2), Иисуса Навина (6), Судей (5), Второзакония (3), 1 и 2 Царств (2 и 3), Чисел (2), из I Послания к Коринфянам (2), из Послания к Евреям (2), Исайи (2), Иеремии (1), Захарии (1), Евангелия от Матфея (1).

Представленный выше обзор типов указаний и заимствований библейского текста для парабиблейского произведения позволяет сделать следующий вывод (он может быть уточнен в ходе дальнейших возможных текстологических исследований): процесс конституирования ИП на библейском материале происходит тремя способами: во-первых - на уровне тематической основы целостного произведения - с помощью выбора соответствующих фрагментов и, в большинстве глав, через оригинальный текст, (по образцу ветхозаветного) и причинно-следственные связи историй. Во-вторых, с помощью включения в текст (как нарратива, так и реплик героев) фрагментов Писания. В-третьих, через ссылки на Писание с помощью цитаты, предваряемой вступлением нарратора ИП, а также через указание на книгу, содержащую формулировки, соответствующие парабиблейскому произведению.

Среди суждений о повествовании в Ветхом Завете можно найти и такие, согласно которым «библейское повествование [...] не поощряет т.н. эстетическое чтение, результатом которого может быть радость вхождения в мир литературной композиции» ${ }^{29}$, тем временем ИП, как парабиблейский текст, тонко реинтерпретирующий источник (с точки зрения нового контекста прочтения библейского текста), без сомнения можно отнести к «художественным», дополнительно эстетизированным текстам. Сила слова ИП состоит главным образом в более четком, чем в гипертексте, прорисовывании отдельных героев и событий, даже если факты, с ними связанные, не выходят за границы библейского материала.

Кажется, что именно характерная сегментация повествования уводит на второй план моральные и религиозные поучения, представляя персонажи (их можно назвать не только историческими, библейскими, но и литературными), которые прежде всего являются центрами отдельных фабул ${ }^{30}$. Сделанный автором ИП выбор - хотя он и не помогает уточнить факты (или скорее прояснить эпизоды), которые имеют историческое значение

${ }^{29}$ Цит. по: Z. PawŁowsкi, Narracja i egzystencja. Genesis w hermeneutyce opowieści [STT 29], Toruń 2013, p. 50.

${ }^{30}$ Во многих частях ИП мы находим прием своеобразной корректировки библейского повествования с помощью включения небиблейского материала (напр., в истории первых колен или Мелхиседека). 
для народа Израиля - показывает индивидуальные черты героев, делает из малоизвестных ветхозаветных персонажей второго плана настоящих dramatis personae, независимо от их исходной (то есть оригинальной, библейской) роли. Так создаются легкие для передачи читателю истории. Позиция ИП согласовывается с библейским посланием, в ней нет слов, сомнительных с богословской или догматической точек зрения, а изменения и дополнения содержания нельзя назвать результатом стремления исказить гипертекст. Кажется, что вмешательство автора ИП вносит больше всего изменений в ту часть повествования, которая связана с точкой зрения нарратора. Такие приемы, как предоставление слова Вирсавии и дочери Иеффая, свидетельствуют о взгляде на повествование скорее с их перспективы, которая отличается от оригинальной, ветхозаветной.

Можно попытаться найти параллели между этой авторской стратегией и определенными принципами литературного творчества средних веков. Например, Александр Наумов подчеркивает, что в средневековье [...] создание текстов не бьло [...] литературной забавой, игрой правил и конвенций, но создаваемой с большой ответственностью записью истории Божьего творения, открытием по мере возможности первозданной Книги Бытия [...]. Твореи, автор, полько воплощяает тип автора. Он не дистаниируется от создаваемого им языкового и титературного сообщения, но каждый раз соединяется с предметом своего описания [...] $]^{31}$, а само творчество иеленаправленно тишено созидательного начала ${ }^{32}$. Безусловное принятие этого тезиса ведет к опасному выводу, согласно которому все отступления ИП от гипертекста являются случайностью, связанной с недостатками памяти и отказом от сверки с фактическим библейским материалом. Полагаю, однако, что активность автора ИП, которую можно заметить в обращении к иным (небиблейским и поэтическим) источникам, в композиции текста, размещенного таким образом, чтобы нарратив был контрапунктом поэзии, вместе с отступлениями, свидетельствует о целенаправленном представлении текста Ветхого Завета в новой форме - форме, отличающейся от первоисточника. В противном случае, какой смысл в переработке Писания? Было бы достаточно выбрать из него фрагменты и представить в неизменном виде, возможно, и с новыми заглавиями.

\footnotetext{
${ }^{31} \mathrm{~W}$ średniowieczu [...] pisanie nie było [...] zabawa literacka, gra reguł i konwencji, lecz odpowiedzialnym zapisywaniem dziejów Bożego stworzenia, odtwarzaniem w miarę możności pierwowzorowej Księgi Bytu, by znaleźćsie w Księdze Żywota. Twórca, autor nie jest sobą, on realizuje typ autora. Nie ma dystansu wobec tworzonego komunikatu językowego i literackiego, każdorazowo wpisuje się $w$ przedmiot swojego opisu, wobec którego jedynie zewnętrzny jest Bóg i w pewnym sensie Jego wybrańcy, цит. по: A.E. Naumow, Biblia w strukturze artystycznej utworów cerkiewnosłowiańskich, Kraków 1983, p. 9.

${ }^{32}$ Ibidem, p. 10.
} 
Примеры множества отсылок к гипертексту, разнообразие способов использования заимствований, специфическая конструкция парабиблейского текста, в которой смешиваются слои изменяемых форм и цитат (главным образом, ветхозаветных) - все это дает представление о том, насколько вдохновляющей была когда-то библейская история ${ }^{33}$. Это позволяет нам утверждать, что способ формирования этого фундаментального компонента ИП был результатом творческого и многопланового подхода ее автора к гипертексту, а кроме того, свидетельством его творческой компетентности и мастерских способностей.

Перевод: Ян МоРАВИЦКИЙ

\section{Библиография}

Adler W., Palaea Historica („The Old Testament Story”). A new translation and introduction, [in:] Old Testament Pseudepigrapha. More noncanonical scriptures, vol. 1, ed. R. BAUcKHAM, J.R. DAvila, A. Panayotov, Michigan 2013, p. 585-672.

Badalanova-Geller F., Cosmogonies and mythopoesis in the Balkans and beyond, SMer 14, 2014, p. $87-147$.

Bӧтtrich Chr., Palaea/Palaja. Ein byzantinisch-slavischer Beitrag zu den europaicheschen Historienbibeln, [in:] Fragmentarisches Wörterbuch. Beiträge zur biblischen Exegese und christlichen Theologie. Horst Balz zum 70 Geburtstag, ed. K. Schiffner, K. Wengt, W. Zager, Stuttgart 2007, p. 304-313.

The Dead Sea Scrolls Reader, t. 3. Parabiblical Texts, ed. by D.W. Parry, E. Tov with the assistance by C. Anderson, Leiden-Brill 2004.

Dziadosz D., Teologiczne przesłanie teofanii Boga pod dębami Mamre (Rdz 18,1-16), [in:] Język Biblii. Od stuchania do rozumienia. XXXII Tydzień Biblijny, Lublin (KUL), 29.-30.11.2003, ed. W. Pikor, Kielce 2005, p. 21-45.

Falk D.K., The Parabiblical Texts. Strategies for Extending the Scriptures among the Dead Sea Scrolls [The Library of Second Temple Studies], Edinburgh 2007.

Jefrreys E., Old Testament "History” and the Byzantine Chronicle, [in:] The Old Testament in Byzantium, ed. P. Magdalino, R. Nelson, Dumbarton Oaks 2010, p. 153-174.

Miltenova A., Reception of Parabiblical (Paratextual) Literature in Mediaeval Bulgaria, FE VI-VII, 2007, p. 9-20.

Mošın V., Cirilski rukopisi Jugoslavenske Akademije, I. dio. Opis rukopisa, Zagreb 1955.

Naumow A.E., Biblia w strukturze artystycznej utworów cerkiewnosłowiańskich, Kraków 1983.

NaUmow A.E., O kartotece cerkiewnosłowiańskich użyć biblijnych, RSI 44, 1983, № 1, p. 21-29.

${ }^{33}$ См., напр., замечания в работе: E. Jeffreys, Old Testament „History” and the Byzantine Chronicle, [in:] The Old Testament in Byzantium, ed. P. Magdalino, R. Nelson, Dumbarton Oaks 2010, p. $153-174$. 
PawŁowski Z., Narracja i egzystencja. Genesis w hermeneutyce opowieści [STT 29], Toruń 2013.

VAssiliev A., Anecdota graeco-byzantina [СПВЛ, t. 11], Москва 1893.

ZowCZAK M., Biblia ludowa. Interpretacje wątków biblijnych w kulturze ludowej, Toruń 2013.

Библия. Книги Священного писания Ветхого и Нового Завета. Синодальный текст [http:// www.biblioteka3.ru/biblioteka/biblija/] (дата обращения 1.07.2016).

БогдАновит Д., Инвентар ћирилских рукописа у Југославији (XI-XVII века), Београд 1982.

ГАРдзАнити М., Библейские изитаты в иерковнославянской книжности, Москва 2014.

ЗАХАРенко Е.Н., Л.Н. КОМАРОвА, И.В. НечАЕвА, Новый словарь иностранных слов: 25000 слов и словосочетаний, Москва 2003.

МЕдАковић Д., Манастир Савина, Београд 1978.

Милтенова А., Палея, [in:] Старобългарска литература. Енциклопедичен речник, еd. Д. ПЕтКАнова, ${ }^{2}$ Велико Търново 2003.

Милтенова А., А. АнгушевА, Апокрифи, [in:] История на българската средновековна титература, еd. А. МилтеновА, София 2009, р. 212-218.

Минчев Г., Пшинская Библия первой четверти XVI века - малоизвестная южнославянская рукопись, содержащая перевод Восьмикнижия, [in:] Священное Писание как фактор языкового и литературного развития. Материалы международной конферениии „Священное Писание как фактор языкового и титературного развития (в ареале авраамических религий)", Санкт-Петербург, 30 июня 2009 г., еd. Е.Н. МещерскАя, Санкт-Петербург 2011, p. $223-240$.

Пикио Р., Функцията на библейските тематични ключове в литературния код на православното, [in:] Р. Пикио, Православното славянство и старобългарската културна традищия, София 1993, p. 385-435.

Риварова 3., 3. ХауПтова, Григоровичев паримејник. Текст со критички апарат, Скопје 1998.

Сизиков А.В., Новозаветнье цитаты в древнерусском переводе Жития Андрея Юродивого, [in:] Священное Писание как фактор языкового и литературного развития. Материаль международной конферениии „Священное Писание как фактор языкового и титературного развития (в ареале авраамических религий)", Санкт-Петербург, 30 июня 2009 г., ed. Е.Н. МещЕРСКАЯ, Санкт-Петербург 2011, p. 158-177.

Станков Р., Историческая Палея - памятник древней болгарской культуры, Pbg 10.4, 1986, p. 55-63.

СТАнчев Кр., За художествена специфика на старобългарската литература, [in:] Кр. СТАнчЕв, Стилистика и жанрове на старобългарската литература, София 1985, p. 5-21.

Творогов О.В., Палея исто-рическая, [in:] Словарь книжников и книжности Древней Руси (вторая половина XIV-XVI в.), pars 1 et 2, ed. Д.С. ЛихАчев, Ленинград 1988-1989, 2, p. $160-161$.

ХРИСТова Б., Е. МУСакова, Е. УЗУНОвА, Опис на славянските рбкописи в Църковно-историческия и архивен институт - София, t. 1. Библейски книги, еd. Кл. Иванова, София 2009. 


\begin{abstract}
On imitative and creative art of parabiblical texts' author. Remarks on biblical quotations in the second Slavic translation of the Palaea historica. The aim of the paper is to present the results of analysis of the biblical quotations and borrowings found in the Palaea Historica ( $^{\text {th }}$ century) in its second Slavic translation, according mostly to the classification of biblical quotations given by M. Garzaniti (2014). Having its narrative material based on the Octateuch as well as the Books of Samuel, Books of Kings and Books of Chronicles, the Palaea contains a variety of adaptations of the biblical text, which provide evidence for the creative usage of the hypertext (through inter al. summary, contamination of episodes, expansion of details, dramaturgization). Literal quotations from the Old and New Testaments also form an important group of such borrowings. Curiously, a part of these play no narrative role, but rather a structural one, as they summarize the meanings of particular chapters (stories).
\end{abstract}

Ключевые слова: Ветхий Завет, Историческая палея, парабиблейские тексты, славянские переводы византийской литературы, обработка гипертекста.

Keywords: Old Testament, Palaea Historica, para-biblical literature, Slavic translations of Byzantine literature, adaptations of the hypertext.

Małgorzata Skowronek

Katedra Filologii Słowiańskiej

Centrum Ceraneum

Uniwersytet Łódzki

ul. Pomorska 171/173

90-236 Łódź, Polska/Poland

malgorzata.skowronek@uni.lodz.pl 